\title{
Typhoon effects on DOC dynamics in a phosphate-limited reservoir
}

\author{
Yu-Fen Tseng ${ }^{1, *}$, Ting-Chang Hsu ${ }^{2, *}$, Yi-Lung Chen ${ }^{2, *}$, Shuh-Ji Kao², \\ Jiunn-Tzong Wu ${ }^{3}$, Ji-Chen $\mathrm{Lu}^{2}$, Chao-Chen Lai ${ }^{1{ }^{*}}$, Hsiang-Yi Kuo ${ }^{4}$, Chih-Hsien Lin ${ }^{1}$, \\ Yoshimasa Yamamoto ${ }^{2}$, Tian Xiao ${ }^{5}$, Fuh-Kwo Shiah ${ }^{1,2,3, * *}$ \\ ${ }^{1}$ Institute of Oceanography, National Taiwan University, Taipei, Taiwan, ROC \\ ${ }^{2}$ Research Center for Environmental Changes, Academia Sinica, Taipei, Taiwan, ROC \\ ${ }^{3}$ Institute of Marine Chemistry and Ecology, National Taiwan Ocean University, Keelong, Taiwan, ROC \\ ${ }^{4}$ Research Center for Biodiversity, Academia Sinica, Taipei, Taiwan, ROC \\ ${ }^{5}$ Key Laboratory of Marine Ecology and Environmental Sciences, Institute of Oceanology, Chinese Academy of Science, \\ Qindao, PR China
}

\begin{abstract}
To explore typhoon effects on dissolved organic carbon (DOC) dynamics, field investigations (tributary and dam site) and laboratory experiments (bioassay and DOC consumption) were conducted in a subtropical reservoir. A tributary survey indicated that after typhoon disruption, upstream areas were the sources of phosphate $(\mathrm{P})$ but not DOC for the dam site located downstream. Bioassay experiments verified P-limitation on bacteria and phytoplankton during summer stratification, and bacteria showed a faster response than algae to added P. Experiments indicated that DOC consumption was determined by the availability of P. The $4 \mathrm{yr}$ typhoon period (June-September) data of the dam site denoted that DOC concentration $(27$ to $270 \mu \mathrm{M} \mathrm{C})$ and its rate of change $(-13$ to $24 \mu \mathrm{M} \mathrm{C} \mathrm{d}^{-1}$ ) varied more dramatically in the weak (2006 and 2007) than in the strong (2004 and 2005) typhoon years. The negative correlation of DOC with the ratio of bacterial production (BP) to primary production (PP) in the euphotic zone $(0$ to $10 \mathrm{~m})$ signified the interactive effects of auto- and heterotrophic processes on DOC variation. In the aphotic zone, the variation of DOC could be ascribed to the change of BP, which showed a positive correlation with P concentrations. This study documents that DOC concentration in the studied system varied at multiple time scales. Such variation can be explained by the decoupling between BP and PP, which is believed to be a function of the limiting nutrient's availability. More importantly, this study suggests that the P supply introduced by strong typhoons might have substantiated a tighter coupling between BP and PP, so that the amplitude of DOC oscillation during the summer period was effectively reduced.
\end{abstract}

KEY WORDS: DOC $\cdot$ Heterotrophic bacteria $\cdot$ Phytoplankton $\cdot$ Microbial loop Resale or republication not permitted without written consent of the publisher

\section{INTRODUCTION}

Dissolved organic carbon (DOC) constitutes $>90 \%$ of total organic carbon in many aquatic ecosystems (Hedges 1992). Thus, to understand the processes regulating DOC dynamics (accumulation and depletion), it is very important to assess the biological pump and global carbon cycling (Longhurst \& Harrison 1989, Carlson et al. 1994, Del Giorgio et al. 1997, Hansell \& Carlson 1998, Williams \& Bowers 1999). In terms of source, DOC may come from ex- ternal sources including riverine inputs and sediment resuspension. Internally, DOC can be generated from food-web processes such as phytoplankton exudation, zooplankton grazing, viral lysis and plankton excretion. Dissolution of particulate organic matter induced by the ecto-hydrolysis processes of attached bacteria has also served as an important DOC source (Cho \& Azam 1988). On the other hand, heterotrophic bacterioplankton (bacteria) are the major organisms responsible for DOC consumption (see Fuhrman 1992, Azam 1998 for review). 
Intuitively, one may expect that DOC may accumulate in surface waters during the productive season (Copin-Montegut \& Avril 1993). Previous studies have shown that DOC could increase temporarily to levels of 280 to $380 \mu \mathrm{MC}$ after blooms of diatoms (Ittekkot et al. 1981) and Phaeocystis (Billen \& Fontigny 1987). In the Sargasso Sea, Carlson et al. (1994) showed that DOC accumulation caused by high primary production in spring could be partially consumed in summer and autumn. The DOC that escaped decomposition by bacteria in the surface waters could be exported down to deeper areas via strong vertical mixing in winter. These studies have confirmed the seasonal phenomenon of DOC accumulation and export. The issue concerning DOC variation at shorter (i.e. intra-seasonal) and longer (i.e. interannual) time scales, however, has seldom been addressed until recently. After analyzing the results of 10 DOC studies conducted in different areas, Thingstad et al. (1997) proposed that DOC accumulation in ocean systems could be achieved by the decoupling of primary production (DOC source) and bacterial production (DOC sink), what they termed the 'malfunctioning microbial-loop'. The term 'malfunctioning' is used here strictly in the sense of DOC consumption unable to match DOC release.

In tropical and sub-tropical Pacific areas, typhoons may occur consecutively in summer. Recent studies have suggested the importance of typhoon enhancement of phytoplankton biomass and primary production in marine (Dickey \& Nelson 1996, Shiah et al. 2000, Lin et al. 2003) and freshwater (Robarts 1987, Kim et al. 2000, Robarts et al. 1998) ecosystems. The enhancement of bacterial activity after storm events in lake (Robarts 1987), reservoir (Hubbard \& Chrzanowski 1986) and marine (Shiah et al. 2000) systems has also been identified. However, the potential impacts of typhoons on DOC and their relationship to the biogenic source and sink have seldom been explored simultaneously. Moreover, all of the typhoon investigations referred to above were single-case studies. A time-series investigation with extensive sampling during multiple typhoon periods might provide more insightful information for biological and chemical (i.e. DOC) responses to typhoons.

The present study examined the processes of limiting nutrient (phosphate) pulses introduced by summer typhoons, and the subsequent effects of the pulses on biogenic interactions (i.e. bacterial activity versus phytoplankton production) and DOC dynamics. Our results suggest that in summer the absence or presence of a strong typhoon, a source of phosphate supply which drives the significant difference between DOC stocks in shallow and deep-water areas, could affect the magnitude of coupling/decoupling between autoand heterotrophic processes.

\section{MATERIALS AND METHODS}

Study site and sampling. The Feitsui reservoir $\left(121^{\circ} 34^{\prime} \mathrm{E}, 24^{\circ} 54^{\prime} \mathrm{N}\right)$ is located in northern Taiwan at an altitude of $300 \mathrm{~m}$ and has a basin area of $10.24 \mathrm{~km}^{2}$ (Fig. 1). This reservoir is well protected from human activities since it has been the drinking water source for Taipei City since the 1980s. The precipitation and wind speed data of the typhoons that occurred during the sampling period were obtained from the Central Weather Bureau, Taiwan (www.cwb.gov.tw/eng/index. $\mathrm{htm}$ ). A typhoon impact index was calculated as the product of precipitation and maximal wind speed. A high wind speed may favor sediment resuspension in the relatively shallow upstream areas, while high precipitation commonly causes high runoff, which may flush the sediment from the tributaries and cause downstream transport. Hydrological data including daily inflow, outflow and reservoir total water volume were provided by the Taipei Feitsui Reservoir Administration (http://english.fra.taipei.gov.tw). These data allowed us to estimate water residence time (= total water volume/outflow rate) of this reservoir.

Field surveys. For the tributary survey, monthly samples of DOC and phosphate (P) were taken at 5 to 12 depths throughout the water column at 5 stations (Fig. 1) along the mainstream of the reservoir from March 2004 to July 2005. Stn 1 was located downstream (i.e. dam site) with a depth of $\sim 100 \mathrm{~m}$. Stn 18 (60 $\mathrm{m}$ deep) was at the conjunction of the mainstream and Ho-Ken-Gi Creek, the largest tributary from the south. Stn 48 (15 m deep) represented the most upstream tributary. Biological measurements were not performed in the present tributary survey.

For the dam site survey, sampling was conducted once a week or once every 2 weeks at Stn 1 from May 2004 to December 2007. Water samples for the measurements detailed below were manually collected

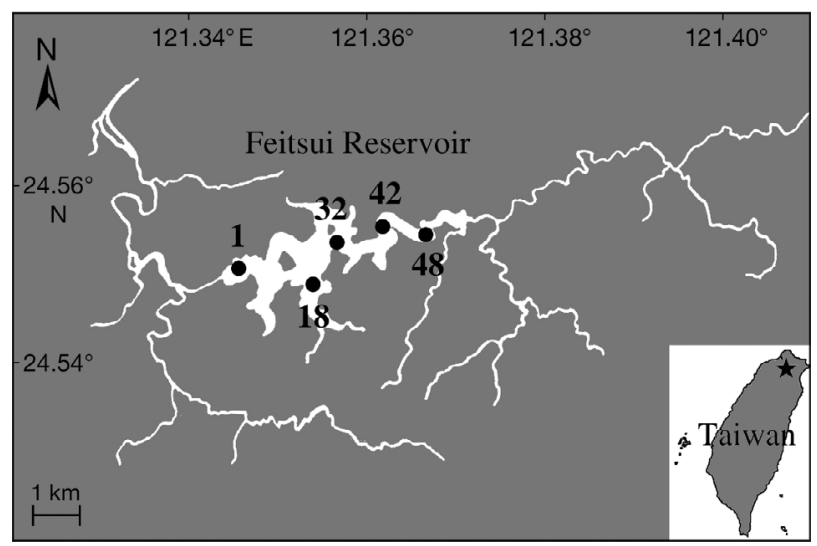

Fig. 1. Study site showing the dam site (Stn 1) and the 4 tributary stations (Stns 18, 32, 42 and 48). Inset: location of study site $(\star)$ in Taiwan 
from 12 depths $(0,1,2,5,10,20,30,40,50,70,80$ and $90 \mathrm{~m}$ ) via a 51 Go-Flo bottle.

In both surveys, the euphotic zone seldom exceeded $15 \mathrm{~m}$. Profiles of temperature, transparency, fluorescence and photosynthetic available radiance were recorded by CTD (IDRONAUT) simultaneously. To explore typhoon effects, data taken from the dam site during the typhoon period (June to September) were analyzed.

$P$ and DOC concentrations. For analysis of $\mathrm{P}$ concentrations (Parsons et al. 1984), pre-filtered (GF/F) water samples were measured via a custom-made flow injection analyzer with a $10 \mathrm{~cm}$ detection cell. The detection limit was $20 \mathrm{nMP}$. Samples for DOC measurement were filtered through pre-combusted $\left(500^{\circ} \mathrm{C}\right) \mathrm{GF} / \mathrm{F}$ filters and then filled into pre-combusted $40 \mathrm{ml}$ vials. After the addition of several drops of $80 \% \mathrm{H}_{3} \mathrm{PO}_{4}$, vials were sealed with pre-combusted aluminum foil and screw caps with Teflon-coated septa. Before analysis, samples were acidified with $80 \% \mathrm{H}_{3} \mathrm{PO}_{4}$ and sparged with $\mathrm{CO}_{2}$ free $\mathrm{O}_{2}$ at a flow rate of $350 \mathrm{ml} \mathrm{min}{ }^{-1}$ for at least $10 \mathrm{~min}$. Samples were analyzed by high temperature catalytic oxidation method using a Shimadzu TOC 5000.

Chlorophyll a concentrations and primary production. Chlorophyll a (chl a) concentrations were determined from samples (in triplicate for each depth) collected with $0.2 \mu \mathrm{m}$ polycarbonate (PC) filters. Pigment fluorescence extracted from the filters was measured with an in vitro fluorometer (Turner Designs 10-AU005) subsequent to acetone extraction (Parsons et al. 1984). Primary production was measured by the ${ }^{14} \mathrm{C}$ assimilation method (Parsons et al. 1984) with 10 neutral density filters (LEE Filters) and incubated for 20 to 60 min in a self-designed tank with an artificial light source $\left(\sim 2000 \mu \mathrm{E} \mathrm{m} \mathrm{m}^{-2} \mathrm{~s}^{-1}\right)$. After incubation and acidification $(0.5 \mathrm{~N} \mathrm{HCl})$, the radioactivity collected in each $0.2 \mu \mathrm{m}$ PC filter was then counted in a scintillation counter (Packard 2200).

Bacterial biomass and production. Bacterial abundance retained on each $0.2 \mu \mathrm{m}$ black PC filter was estimated by the acridine orange direct count method (Hobbie et al. 1977) and epifluorescence microscopy (Axioplan 2, Zeiss). Bacterial activity was measured by ${ }^{3} \mathrm{H}$-thymidine incorporation (Fuhrman \& Azam 1982). The radioactivity retained in the $0.2 \mu \mathrm{m}$ ethyl-acetate filter was detected by a scintillation counter (Packard 2200) after the samples were rinsed with icecold trichloroacetic acid and ice-cold ethyl alcohol (85\%) 3 times each. Thymidine conversion factor (TCF, 2.2 to $3.1 \times 10^{18}$ cell mol $^{-1}$ ) was determined empirically following the seawater culture method (Ammerman et al. 1984), which was conducted in summer
(August) and autumn (November) 2004 as well as winter (February) and spring (April) 2005. Bacterial biomass and production in $\mathrm{C}$ units were obtained by these empirically derived TCFs and a carbon conversion factor of $20 \mathrm{fgC} \mathrm{cell}^{-1}$ (Ducklow \& Carlson 1992).

Bioassay experiment. Four bioassay experiments were conducted in June to September 2007 (Table 1). The surface water ( $5 \mathrm{~m}$ depth) taken from the dam site was filtered through a $3 \mu \mathrm{m}$ PC filter via gravity filtration. In each experiment, filtrates in triplicate $11 \mathrm{PC}$ bottles were subjected to 4 treatments: the non-amended control and P-, glucose (C)- and ammonium(N)-enriched treatments. The final concentrations of the $\mathrm{P}-$, $\mathrm{C}$ - and N-enriched treatments were $200 \mathrm{nMP}, 50 \mu \mathrm{MC}$ and $500 \mathrm{nMN}$, respectively. All treatments then were incubated at in situ temperature under a $12 \mathrm{~h}$ light: $12 \mathrm{~h}$ dark cycle (Table 1) for $72 \mathrm{~h}$. Bacteria and cyanobacteria (constituted $>90 \%$ of total algal abundance in the field; F. K. Shiah unpubl. data) were subsampled every 12 to $24 \mathrm{~h}$ for abundance estimation. DOC and P concentrations were monitored in Expt 4 only. For cyanobacteria abundance, auto-fluorescence retained on a $0.2 \mu \mathrm{m}$ black PC filter was enumerated under an epifluorescence microscope (Axioplan 2, Zeiss).

DOC consumption experiments. Seven DOC consumption experiments were conducted during February to May 2008 (Table 2). Filtrates (3.0 $\mu \mathrm{m}$ PC filter, gravity filtration) of the surface water from the dam site were filled into duplicate $250 \mathrm{ml}$ PC bottles and then incubated in the dark for $24 \mathrm{~h}$ at room temperature $\left(25^{\circ} \mathrm{C}\right)$. Incubating at fixed temperature allowed for the analysis of ambient and/or added $\mathrm{P}$ effects on DOC consumption without the interference of temperature. The net DOC consumption rate was calculated as the difference between the initial and final DOC readings with an assumption of linear depletion. In the 13 May experiment (Table 2), a parallel P-enrichment incubation (final concentration $100 \mathrm{nMP}$ ) was conducted.

Data management and statistical analysis. The trapezoidal method was applied to derive integrated values of the euphotic ( 0 to $10 \mathrm{~m}$ ) and aphotic (10 to

Table 1. In situ conditions of temperature $(\mathrm{T})$, concentrations of dissolved organic carbon (DOC), phosphate (P), dissolved inorganic nitrogen (DIN; nitrate + nitrite + ammonium) and silicate (Si) and light intensity for the 4 bioassay experiments conducted in summer 2007. Concentrations of DIN (nitrate, nitrite and ammonium) and Si were measured following the methods of Parsons et al. (1984). DL: detection limit, $20 \mathrm{nMP}$

\begin{tabular}{|cccccccc|}
\hline Expt & Date & $\begin{array}{c}\mathrm{T} \\
\left({ }^{\circ} \mathrm{C}\right)\end{array}$ & $\begin{array}{c}\text { DOC } \\
(\mu \mathrm{MC})\end{array}$ & $\begin{array}{c}\mathrm{P} \\
(\mathrm{nMP})\end{array}$ & $\begin{array}{c}\mathrm{DIN} \\
(\mu \mathrm{MN})\end{array}$ & $\begin{array}{c}\mathrm{Si} \\
(\mu \mathrm{M})\end{array}$ & $\begin{array}{c}\text { Light intensity } \\
\left(\mu \mathrm{E} \mathrm{m}^{-2} \mathrm{~s}^{-1}\right)\end{array}$ \\
\hline 1 & 12 Jun & 26 & 86 & $<\mathrm{DL}$ & 33 & 50 & 28 \\
2 & 3 Jul & 30 & 226 & $<\mathrm{DL}$ & 33 & 25 & 76 \\
3 & 14 Aug & 29 & 113 & 25 & 31 & 28 & 44 \\
4 & 11 Sep & 28 & 116 & $<\mathrm{DL}$ & 30 & 68 & 42 \\
\hline
\end{tabular}


Table 2. In situ physical (temperature [T]) and chemical conditions of the 7 DOC consumption experiments conducted in 2008 and the DOC consumption rates derived from these experiments. P: phosphate; DIN: dissolved inorganic nitrogen; Si: silicate. All incubations were conducted at room temperature $\left(25^{\circ} \mathrm{C}\right)$. DL: detection limit, $20 \mathrm{nMP}$

\begin{tabular}{|c|c|c|c|c|c|c|c|}
\hline Expt & Date & $\begin{array}{l}\mathrm{T} \\
\left({ }^{\circ} \mathrm{C}\right)\end{array}$ & $\begin{array}{c}\text { Ambient } \\
\text { DOC } \\
(\mu \mathrm{MC})\end{array}$ & $\begin{array}{c}\mathrm{P} \\
(\mathrm{nMP})\end{array}$ & $\begin{array}{c}\mathrm{DIN} \\
(\mu \mathrm{MN})\end{array}$ & $\underset{(\mu \mathrm{M})}{\mathrm{Si}}$ & $\begin{array}{c}\text { DOC } \\
\text { consumption } \\
\text { rate }\left(\mu \mathrm{MC} \mathrm{d}^{-1}\right)\end{array}$ \\
\hline 1 & 12 Feb & 17.6 & 65.1 & 129 & 65 & 132 & 18.4 \\
\hline 2 & $11 \mathrm{Mar}$ & 17.7 & 90.3 & 86 & 66 & 137 & 18.4 \\
\hline 3 & $01 \mathrm{Apr}$ & 19.3 & 49.1 & 33 & 58 & 125 & 11.4 \\
\hline 4 & 15 Apr & 21.7 & 51.3 & 56 & 58 & 129 & 14 \\
\hline 5 & $29 \mathrm{Apr}$ & 22.5 & 92.8 & 24 & 51 & 139 & 4.3 \\
\hline 6 & 13 May & 23.4 & 60.2 & $<\mathrm{DL}$ & 48 & 139 & 4.1 \\
\hline 7 & 13 May $^{a}$ & 23.4 & 60.2 & 100 & 48 & 139 & 17.9 \\
\hline \multicolumn{7}{|c|}{$\begin{array}{l}\text { Mean } \pm \text { SD } \\
\text { a P-enrichment experiment }\end{array}$} & $12.6 \pm 6.3$ \\
\hline
\end{tabular}

(April) of the following year. The wet season starts in mid-spring (May) when the mild but persisting plume-rain prevails, followed by typhoon rain and afternoon thunder showers, the major precipitation sources in summer. Rainfall induced by typhoons, although rare, could be many times higher than the plume-rain and/or afternoon thunder showers (www.cwb.gov.tw/eng/index.htm). Rates of precipitation and water inflow during the 4 typhoon periods ranged from 0 to $76 \mathrm{~mm} \mathrm{~d}^{-1}$ and 0.36 to $22.4 \times 10^{6} \mathrm{~m}^{3} \mathrm{~d}^{-1}$, respectively. Reservoir water volume $\left(207\right.$ to $\left.313 \times 10^{6} \mathrm{~m}^{3}\right)$ showed a positive correlation with the inflow rate $(\mathrm{r}=0.43$, $\mathrm{n}=63, \mathrm{p}<0.01$ ), which was a positive function of precipitation $(\mathrm{r}=0.94, \mathrm{n}=63$,

$90 \mathrm{~m})$ zones. The depth-averaged values were calculated by dividing the integrated value by the depth used in integration. Net DOC accumulation and depletion rates were calculated from the difference in DOC concentration between 2 sampling points at which DOC concentrations were increasing and decreasing, respectively. A linear correlation method was applied first to examine the relationships among depth-averaged measurements. In regression analysis (linear and multiple, Edwards 1985), some of the measurements were logarithmically transformed to get a better fit. Analysis of covariance (ANCOVA) was used to compare the slopes of regression lines.

\section{RESULTS}

\section{Reservoir hydrology}

At the study site, the dry season occupies the period from autumn (October to December) to early spring $\mathrm{p}<0.01)$. Reservoir water residence time varied from 12 to $648 \mathrm{~d}$ with a mean \pm SD of $169 \pm 155 \mathrm{~d}$.

\section{Tributary study}

Depth-averaged DOC concentrations in the euphotic zone $\left(\mathrm{DOC}_{\mathrm{EU}}\right)$ at the 4 tributary stations (45 to $110 \mu \mathrm{MC}$ ) generally were similar to those of the dam site (Fig. 2A). Temporally, DOC $\mathrm{EU}_{\mathrm{EU}}$ concentrations were low in winter (January to March), increased in spring (April to June) and reached maxima in summer (July to September). In terms of spatial variation, $\mathrm{DOC}_{\mathrm{EU}}$ Concentrations at the dam site showed little difference with those of the tributary stations except in April and autumn (October-November) 2004, when concentrations were higher at the dam site. Note specifically that during the typhoon period, $\mathrm{DOC}_{\mathrm{EU}}$ readings at the dam site (Fig. 2A) were either similar to or higher than those of the tributaries, despite high tributary discharge. Depth-averaged P concentrations in the euphotic zone
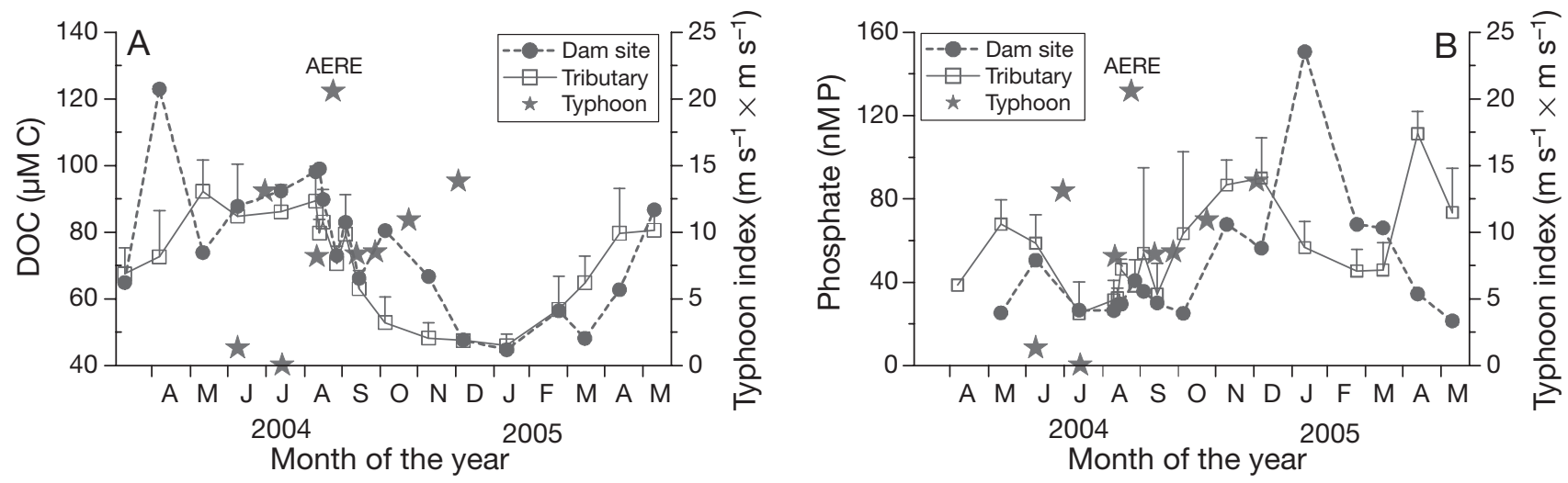

Fig. 2. Monthly change in depth-averaged (A) dissolved organic carbon (DOC) and (B) phosphate concentrations in the euphotic zone derived from the tributary study. Vertical bars represent SD. Aere, the strongest typhoon, occurred in 2004 
$\left(\mathrm{P}_{\mathrm{EU}}\right)$ at the tributaries ( $<20$ to $\left.121 \mathrm{nM} \mathrm{P}\right)$ generally were either similar to or higher than those of the dam site (Fig. 2B), except in the winter, when a reverse trend was observed. In the surface waters, some typhoons, particularly the strong ones, did render obvious $\mathrm{P}_{\mathrm{EU}}$ concentration differences between the tributaries (higher) and the dam site (lower).

Two summer (16 August and 3 September 2004) vertical profiles are given to address typhoon effects. Fig. 3A represents the normal summer DOC profile. There, DOC concentrations at all stations throughout the basin were high at the surface and decreased with depth. Horizontally, the $80 \mu \mathrm{MC}$ isoline coincided with depths of $\sim 5 \mathrm{~m}$ upstream and gradually deepened

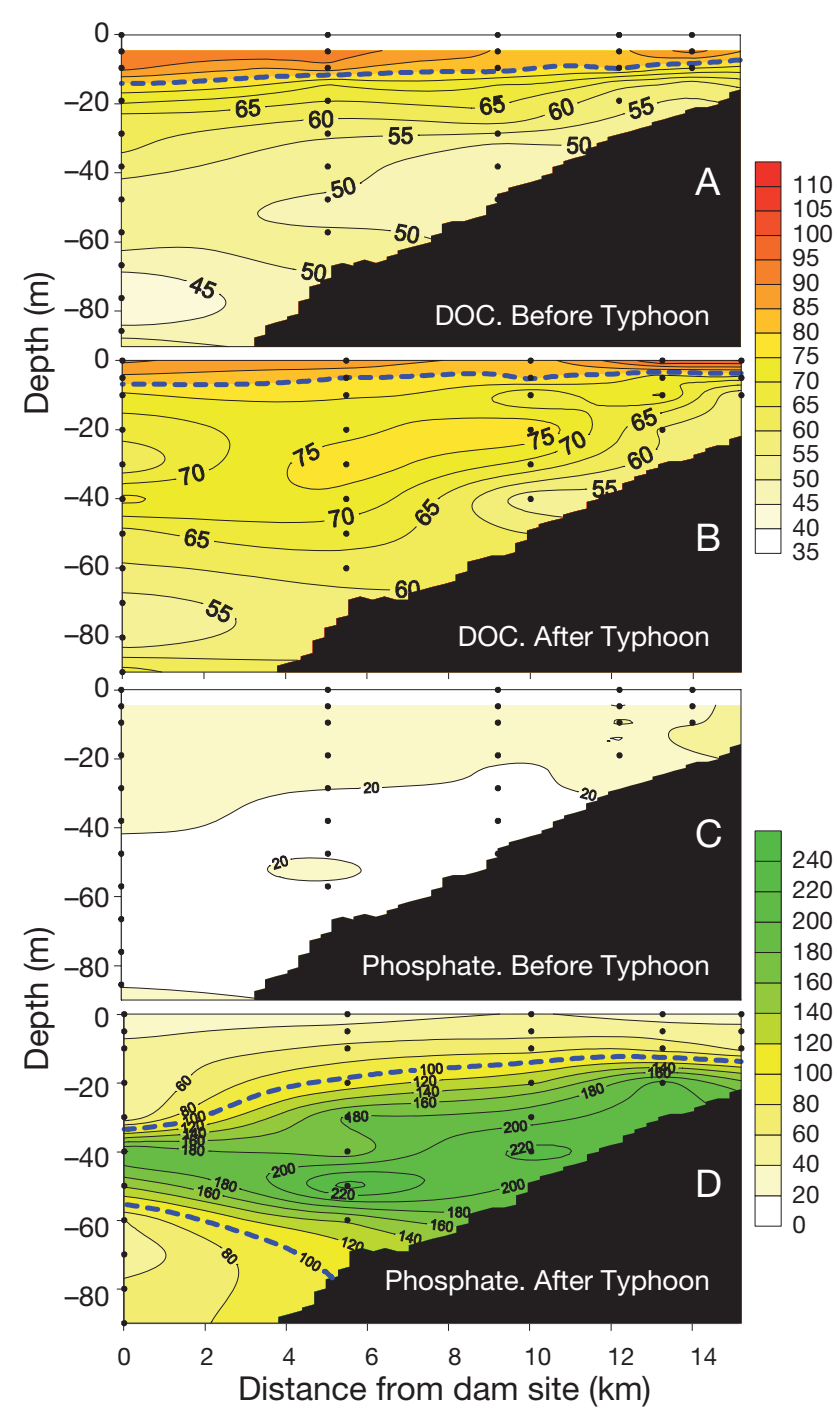

Fig. 3. Vertical contours of $(A, B)$ dissolved organic carbon $(\mathrm{DOC}, \mu \mathrm{MC})$ and $(\mathrm{C}, \mathrm{D})$ phosphate (nMP) concentrations before and after typhoon Aere. Dashed lines in $(\mathrm{A}, \mathrm{B})$ and $(\mathrm{C}, \mathrm{D})$ indicate DOC $80 \mu \mathrm{MC}$ and phosphate $100 \mathrm{nMP}$ isolines, respectively. Solid dots indicate sampling depths down to $\sim 10 \mathrm{~m}$ at the dam site. The DOC contour shown in Fig. 3B was recorded $8 \mathrm{~d}$ after the passage of typhoon Aere (23 to 26 August). In this post-typhoon case, the depth of the $80 \mu \mathrm{MC}$ isoline along the mainstream turned shallower when compared with that in the pre-typhoon case. A DOC subsurface plume at depths of 30 to $50 \mathrm{~m}$ was observed at mid-stream (Fig. 3B). However, its concentrations (75 to $78 \mu \mathrm{MC}$ ) were only several $\mu \mathrm{MC}$ higher than those of the same depth range at the dam site.

Unlike DOC, vertical P profiles showed a large distinction before (Fig. 3C) and after (Fig. 3D) typhoon Aere. Before the typhoon, $\mathrm{P}$ readings throughout the reservoir were very close to detection limits of $20 \mathrm{nM} \mathrm{P}$, except those recorded at the most upstream station (Stn 48). After typhoon invasion, $\mathrm{P}$ readings at all depths throughout the reservoir increased significantly, and a subsurface P plume with concentrations >100 nMP (Fig. 3D) was observed in mid-water.

\section{Dam site study}

Surface temperature (Fig. $4 \mathrm{~A}$ ) varied by $>14^{\circ} \mathrm{C}$, with lower temperatures $\left(<17^{\circ} \mathrm{C}\right)$ in winter and higher temperatures $\left(>31^{\circ} \mathrm{C}\right)$ in summer. The deepening of the mixed layer depth (MLD, the depth at which the temperature is $0.25^{\circ} \mathrm{C}$ lower than the surface; Fig. $4 \mathrm{~A}$ ) was initiated in October and reached depths of $>60 \mathrm{~m}$ in winter. MLD turned shallow in March and was maintained at depths $<10 \mathrm{~m}$ until September. Weekly averaged light intensity (8 to $106 \mathrm{mmol} \mathrm{E} \mathrm{m}^{-2} \mathrm{~d}^{-1}$; Fig. 4B) basically varied synchronously with temperature. A total of 29 (Fig. 4B) typhoons were recorded during the study period. Half of the typhoons that occurred in 2004 and 2005 were strong with impact indices $>10 \mathrm{~m}$ $\mathrm{s}^{-1} \times \mathrm{m} \mathrm{s}^{-1}$. On the other hand, all typhoons recorded in 2006 and 2007 were very weak, with only one exception in 2007. The first $2 \mathrm{yr}$ and last $2 \mathrm{yr}$ are therefore referred to as strong typhoon years (STY) and weak typhoon years (WTY), respectively.

Seasonal $\mathrm{P}_{\mathrm{EU}}(<20$ to $150 \mathrm{nMP}$; Fig. 4C) concentrations were generally close to detection limits, except several spikes that occurred during post-typhoon periods and winter, when vertical mixing was the strongest. Euphotic zone depth-integrated nitrate concentrations during summer were all measurable with a range of 3.9 to $43 \mu \mathrm{MN}$ (present study, F. K. Shiah unpubl. data). This gave an average N:P molar ratio of $955 \pm 747$ (range $=127$ to 3500), much higher than the Redfield ratio $(\mathrm{N}: \mathrm{P}=106: 1$; Redfield et al. 1963). Vertical profiles of individual $P$ concentrations (Fig. 5A) showed a significant summer subsurface plume ( $p>100 \mathrm{nM}$ ) occurring at depths of 40 to $80 \mathrm{~m}$, reflecting the footprint of hyperpycnal flow induced 

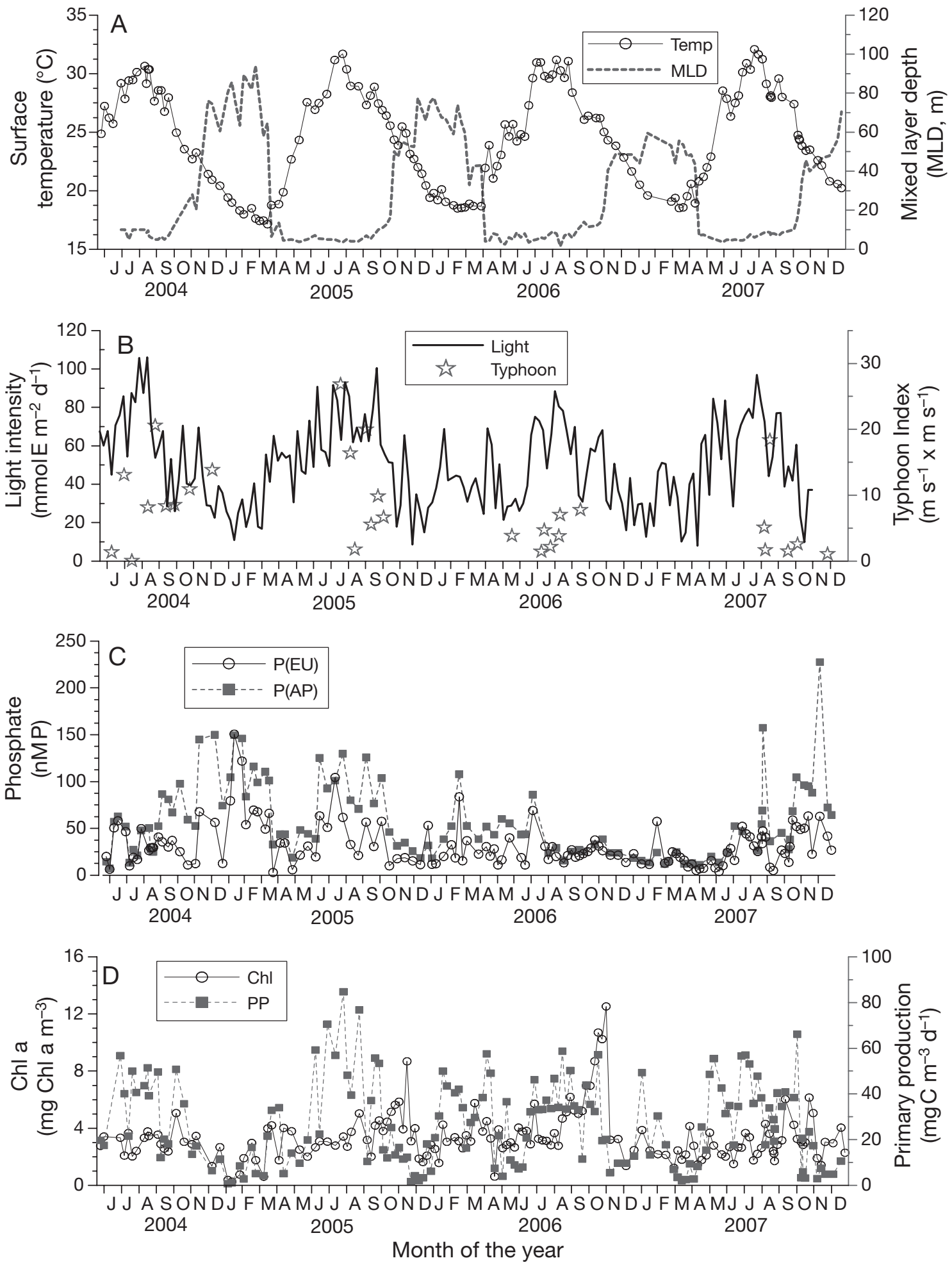

Fig. 4. Time series of depth-averaged euphotic (EU) and aphotic (AP) zone measurements derived from the dam site study. (A) Surface temperature $\left({ }^{\circ} \mathrm{C}\right)$ and mixed layer depth $(\mathrm{MLD}, \mathrm{m}) ;(\mathrm{B})$ light intensity $\left(\mathrm{mmol} \mathrm{E} \mathrm{m}^{-2} \mathrm{~d}^{-1}\right)$ and typhoon index $\left(\mathrm{m} \mathrm{s}{ }^{-1} \times\right.$ $\left.\mathrm{m} \mathrm{s}^{-1}\right)$; (C) phosphate (P) concentration (nMP); (D) chlorophyll a (chl a) concentration $\left(\mathrm{mg} \mathrm{chl} \mathrm{a} \mathrm{m}^{-3}\right.$ ) and primary production (PP, $\left.\mathrm{mg} \mathrm{C} \mathrm{m}^{-3} \mathrm{~d}^{-1}\right)$; (E) bacterial biomass $\left(\mathrm{BB}, \mathrm{mg} \mathrm{C} \mathrm{m}^{-3}\right)$; $(\mathrm{F})$ bacterial production $\left(\mathrm{BP}, \mathrm{mg} \mathrm{C} \mathrm{m}^{-3} \mathrm{~d}^{-1}\right)$; (G) dissolved organic carbon $(\mathrm{DOC}, \mu \mathrm{MC})$; and $(\mathrm{H})$ net DOC change rate $\left(\mu \mathrm{MC} \mathrm{d}^{-1}\right)$. Numbers 1 to $10 \mathrm{in}(\mathrm{G})$ indicate the 10 cases of high DOC concentrations given in the 'Discussion' 

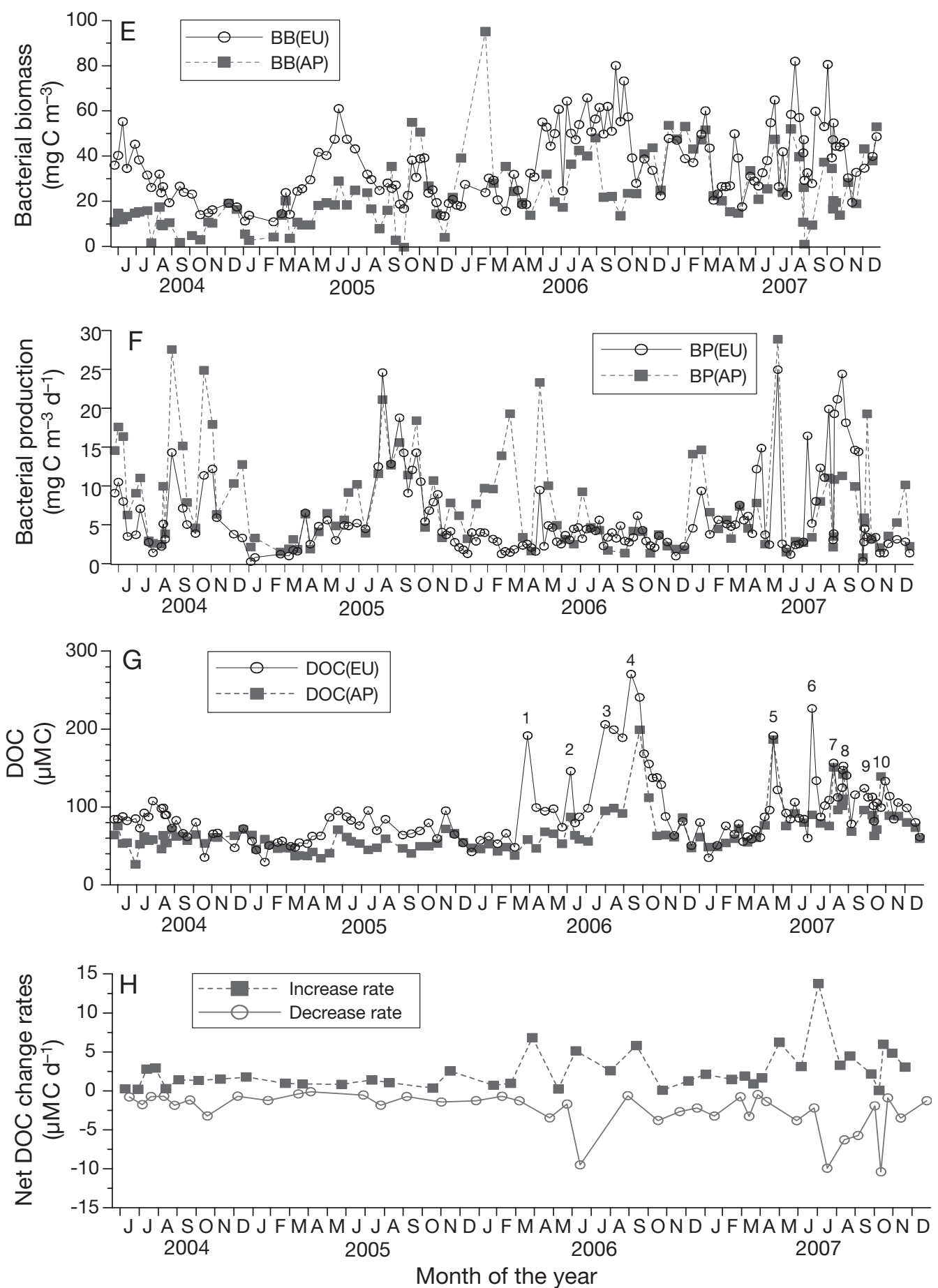

Fig. 4 (continued)

by strong typhoons (Chen et al. 2006). No subsurface P plume was observed in the summer of 2006 when all typhoons were very weak. Depth-averaged $\mathrm{P}$ concentrations in the aphotic zone $\left(\mathrm{P}_{\mathrm{AP} i}<20\right.$ to 228 nMP; Fig. 4C) changed synchronously with $\mathrm{P}_{\mathrm{EU}}(\mathrm{r}=$ $0.74, \mathrm{n}=107, \mathrm{p}<0.01)$, but their values were on average $\sim 70 \%$ higher.
Euphotic zone depth-averaged chl a concentrations

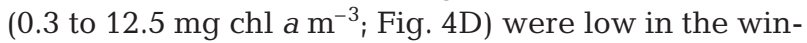
ter. Algal blooms ( $>5 \mathrm{mg} \mathrm{chl} \mathrm{a} \mathrm{m}^{-3}$ ) occurred in autumn but not spring. Summer algal biomass was maintained at values $\sim 3 \mathrm{mg} \mathrm{chl} \mathrm{a} \mathrm{m}^{-3}$ and showed no significant interannual difference. Depth-averaged primary production ( $\mathrm{PP} ; 0.7$ to $85 \mathrm{mg} \mathrm{C} \mathrm{m} \mathrm{d}^{-3}$; Fig. 4D) varied 

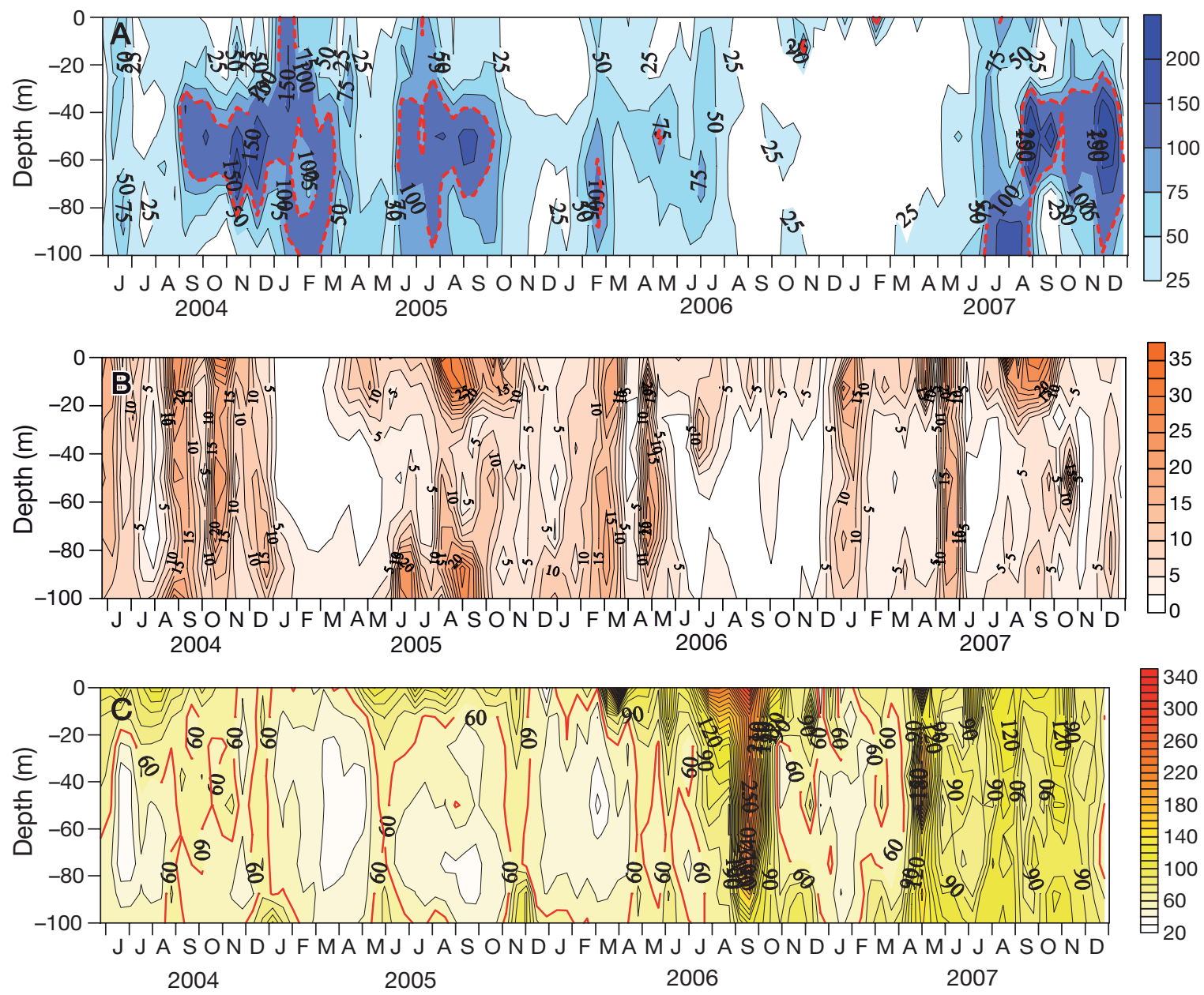

Fig. 5. Depth contours of the measurements from the dam site study. (A) Phosphate (P, nMP), (B) bacterial production (BP, mg C $\mathrm{m}^{-3} \mathrm{~d}^{-1}$ ) and $(\mathrm{C})$ dissolved organic carbon (DOC) concentrations ( $\mu \mathrm{MC}$ ). Dashed and solid red lines in (A) and (C), respectively, indicate phosphate $100 \mathrm{nMP}$ and DOC $60 \mu \mathrm{MC}$ isolines, respectively

$>80$-fold during the study period, with the highest PP values occurring in summer, although occasionally PP peaked in spring and even winter. Light intensity was the best factor explaining the seasonal variation of primary production. The slope during STY $(0.58 \pm$ $0.08 \mathrm{mg} \mathrm{C} \mathrm{m}^{-3} \mathrm{~d}^{-1} / \mathrm{mmol} \mathrm{E} \mathrm{m}^{-2} \mathrm{~d}^{-1} ; \mathrm{n}=59, \mathrm{r}^{2}=0.46, \mathrm{p}<$ 0.01 ) was significantly higher than that during WTY $\left(0.52 \pm 0.06 \mathrm{mg} \mathrm{C} \mathrm{m}^{-3} \mathrm{~d}^{-1} / \mathrm{mmol} \mathrm{E} \mathrm{m}{ }^{-2} \mathrm{~d}^{-1} ; \mathrm{n}=88, \mathrm{r}^{2}=\right.$ $0.44, \mathrm{p}<0.01$; ANCOVA, $\mathrm{p}<0.05$ ).

Bacterial biomass in the euphotic zone $\left(\mathrm{BB}_{\mathrm{EU}} ; 1\right.$ to $82 \mathrm{mg} \mathrm{C} \mathrm{m}^{-3}$; Fig. 4 E) varied $\sim 8$-fold. $\mathrm{BB}$ in the aphotic zone $\left(\mathrm{BB}_{\mathrm{AP}} ; 10\right.$ to $58 \mathrm{mg} \mathrm{C} \mathrm{m}^{-3}$; Fig. $\left.4 \mathrm{E}\right)$ showed a trend similar to that of $\mathrm{BB}_{\mathrm{EU}}(\mathrm{r}=0.45, \mathrm{n}=101, \mathrm{p}<0.01)$, but with values $\sim 70 \%$ lower. Profiles of bacterial production (BP; Fig. 5B) indicated that bacterial activity was generally high in the surface waters, and then decreased with depth. There were several cases showing high BP throughout the water column, which could be seen during the periods of June to December 2004 and
January to May 2006. Depth-averaged BP in the euphotic zone ( $\mathrm{BP}_{\mathrm{EU}} ; 0.1$ to $25 \mathrm{mg} \mathrm{C} \mathrm{m}^{-3} \mathrm{~d}^{-1}$; Fig. $4 \mathrm{~F}$ ) as a whole was about $16 \%$ of PP. In terms of seasonal variation, $\mathrm{BP}_{\mathrm{EU}}$ concentrations were seldom in phase with PP. Neither the data sets of the whole $(\mathrm{n}=144)$ nor the typhoon sampling period $(\mathrm{n}=51)$ indicated a significant correlation between $\mathrm{PP}$ and $\mathrm{BP}_{\mathrm{EU}}$. Depth-averaged $\mathrm{BP}$ in the aphotic zone $\left(\mathrm{BP}_{\mathrm{AP}} ; 0.3 \sim 28 \mathrm{mg} \mathrm{C} \mathrm{m}^{-3} \mathrm{~d}^{-1}\right.$; Fig. $\left.4 \mathrm{~F}\right)$ changed synchronously $(\mathrm{r}=0.82, \mathrm{n}=103, \mathrm{p}<0.01)$ with $\mathrm{BP}_{\mathrm{EU}}$, but with values $20 \%$ higher. Note that in the first $2 \mathrm{yr}$, both $\mathrm{BP}_{\mathrm{EU}}(\mathrm{r}=0.43, \mathrm{n}=40, \mathrm{p}<0.01)$ and $\mathrm{BP}_{\mathrm{AP}}(\mathrm{r}=$ $0.33, \mathrm{n}=47, \mathrm{p}<0.01$ ) changed proportionally with temperature, with peak values appearing in summer. On the other hand, such a seasonal pattern was not seen in the summer of 2006 and was less significant in 2007.

In the euphotic zone, $\mathrm{DOC}_{\mathrm{EU}}$ varied 9-fold with values ranging from 29 to $270 \mu \mathrm{MC}$ (Fig. 4G) Depth-averaged DOC concentrations in the aphotic zone (DOC $\mathrm{AP}_{\mathrm{AP}}$ 27 to $199 \mu \mathrm{MC}$, Fig. 4G) varied almost simultaneously 
with $\mathrm{DOC}_{\mathrm{EU}}(\mathrm{r}=0.73, \mathrm{n}=109, \mathrm{p}<0.01)$. The ratio of DOC $_{\mathrm{AP}}$ to $\mathrm{DOC}_{\mathrm{EU}}$ was $\sim 50 \%$. Net DOC $\mathrm{EU}$ accumulation and depletion rates ranged from $<0.1$ to 13.8 and -0.1 to $-13.2 \mu \mathrm{M} \mathrm{C} \mathrm{d}^{-1}$, respectively (Fig. $4 \mathrm{H}$ ). These 2 rates appeared alternately during the sampling period. Interannually, higher net $\mathrm{DOC}_{\mathrm{EU}}$ accumulation and depletion rates (i.e. $> \pm 5 \mu \mathrm{MC} \mathrm{d}^{-1}$ ) were observed in WTY only. Net DOC accumulation $(<0.01$ to $10.7 \mu \mathrm{MC}$ $\left.\mathrm{d}^{-1}\right)$ and depletion $\left(-0.02\right.$ to $\left.-7.8 \mu \mathrm{MC} \mathrm{d}^{-1}\right)$ rates in the aphotic zone followed the same pattern of those in the euphotic zone.

Vertically, DOC concentrations were higher at the surface and then decreased with depth (Fig. 5C). In spring and autumn, the entire water column was regularly occupied by DOC concentrations $>60 \mu \mathrm{MC}$ (i.e. DOC anomaly). A DOC anomaly also occurred in summer, but in WTY only. For instance, despite strong stratification, a summer anomaly in 2006 was initiated in July, the $80 \mu \mathrm{MC}$ isoline reached the bottom in August, and then the anomaly peaked in mid-September with the $240 \mu \mathrm{MC}$ isoline located at the bottom. The concurrence of several high DOC peaks in the near-bottom waters implied that DOC escaped from sediment mineralization (Fig. 5C), which might also contribute to the formation of a DOC anomaly.

\section{Typhoon effect analysis}

To analyze typhoon effects, measurements collected during the warm stratified periods (June to September) were compared (Table 3). In STY, the typhoon impact was 2-fold stronger and ambient $\mathrm{P}$ concentrations as well as PP were $20 \%$ higher. However, DOC concentrations in WTY were at least $60 \%$ higher than those in STY. Interannual differences in DOC change rates was even more dramatic. For example, net $\mathrm{DOC}_{\mathrm{EU}}$ change rates in WTY were $\sim 4$-fold those in STY. Algal biomass showed no significant difference between STY and WTY. However, the $\mathrm{BP}_{\mathrm{EU}} / \mathrm{PP}$ ratio in WTY $(0.12 \pm 0.09)$ was $40 \%$ of that in STY $(0.27 \pm 0.40)$, which was mainly due to the much lower BP $\mathrm{EU}_{\mathrm{EU}}$ (Table 3, Figs. 4F \& 5B) in WTY.

${ }_{\text {DOC }}$ EU data taken from STY, WTY and pooled (i.e. STY + WTY) data sets all showed a negative correlation with the $\mathrm{BP}_{\mathrm{EU}} / \mathrm{PP}$ ratio (Fig. 6A). The slope of the $\mathrm{BP}_{\mathrm{EU}} / \mathrm{PP}$ ratio on $\mathrm{DOC}_{\mathrm{EU}}$ in $\operatorname{STY}(-0.082 \pm 0.028)$ was not different from that in WTY $(-0.086 \pm 0.032$, ANCOVA, $\mathrm{P}>0.05)$. The correlation between the ratio and $\mathrm{P}$ concentrations in surface waters was not significant. However, the ratio changed positively with the depth-averaged $\mathrm{P}$ concentrations of the whole water column ( $\mathrm{P}_{\mathrm{WC}}$ Fig. 6B). Further analysis indicated that $\mathrm{BP}_{\mathrm{EU}}$, but not PP, was correlated with $\mathrm{P}_{\mathrm{WC}}(\mathrm{r}=0.37, \mathrm{n}=$ $36, \mathrm{p}<0.01$ ). This indicated that the statistical relationship between the ratio and $\mathrm{P}_{\mathrm{WC}}$ resulted from the relationship between $\mathrm{P}_{\mathrm{WC}}$ and $\mathrm{BP}_{\mathrm{EU}}$. For the aphotic zone, we found $\mathrm{BP}_{\mathrm{AP}}$ to be factor that best illustrated the changes in $\mathrm{DOC}_{\mathrm{AP}}$ (Fig. 6C). Additionally, $\mathrm{BP}_{\mathrm{AP}}$ showed a positive correlation with $\mathrm{P}_{\mathrm{AP}}$ (Fig. 6D).

\section{Bioassay experiments}

All 4 bioassay experiments were conducted in warm $\left(>26^{\circ} \mathrm{C}\right)$ conditions at extremely low ambient $\mathrm{P}$ concentrations (Table 1). The results of the 4 experi-

Table 3. Comparison of mean $( \pm$ SD) measurements collected during June to September of the strong (STY, 2004 and 2005) and weak typhoon (WTY, 2006 and 2007) years. P: phosphate; PP: primary production; DOC: dissolved organic carbon; chl a: chlorophyll $a_{i}$ BP: bacterial production. * : significantly different from STY at $\mathrm{p}<0.05$

\begin{tabular}{|c|c|c|c|c|}
\hline Variable & Units & STY & WTY & WTY/STY \\
\hline Typhoon index & $\mathrm{m} \mathrm{s}^{-1} \times \mathrm{m} \mathrm{s}^{-1}$ & $10.7 \pm 7.5$ & $5.2 \pm 4.3^{*}$ & 0.5 \\
\hline \multicolumn{5}{|l|}{ Euphotic zone } \\
\hline $\mathrm{P}$ & nMP & $40 \pm 20$ & $27 \pm 15^{*}$ & 0.7 \\
\hline PP & $\mathrm{mgC} \mathrm{m^{-3 }} \mathrm{d}^{-1}$ & $44 \pm 20$ & $36 \pm 12^{*}$ & 0.8 \\
\hline DOC & $\mu \mathrm{MC}$ & $83 \pm 12$ & $136 \pm 55^{*}$ & 1.6 \\
\hline DOC +rate & $\mu \mathrm{MC} \mathrm{d}^{-1}$ & $1.18 \pm 1.07$ & $6.84 \pm 7.86^{*}$ & 5.8 \\
\hline DOC-rate & $\mu \mathrm{MC} \mathrm{d}^{-1}$ & $1.18 \pm 1.08$ & $4.40 \pm 3.94^{*}$ & 3.7 \\
\hline Chl a & $\mathrm{mg} \operatorname{chl} a \mathrm{~m}^{-3}$ & $3.2 \pm 0.8$ & $3.6 \pm 1.4$ & \\
\hline BP & $\mathrm{mgC} \mathrm{m} \mathrm{m}^{-3} \mathrm{~d}^{-1}$ & $8.1 \pm 5.9$ & $3.6 \pm 2.0^{*}$ & 0.4 \\
\hline $\mathrm{BP} / \mathrm{PP}$ ratio & & $0.27 \pm 0.40$ & $0.12 \pm 0.09^{*}$ & 0.4 \\
\hline \multicolumn{5}{|l|}{ Aphotic zone } \\
\hline $\mathrm{P}$ & nMP & $64 \pm 34$ & $46 \pm 34^{*}$ & 0.7 \\
\hline DOC & $\mu \mathrm{MC}$ & $54 \pm 9$ & $97 \pm 34^{*}$ & 1.8 \\
\hline DOC +rate & $\mu \mathrm{MC} \mathrm{d}^{-1}$ & $1.54 \pm 2.13$ & $3.57 \pm 3.54^{*}$ & 2.3 \\
\hline DOC -rate & $\mu \mathrm{MC} \mathrm{d}^{-1}$ & $1.41 \pm 1.03$ & $2.13 \pm 3.16^{*}$ & 1.5 \\
\hline $\mathrm{BP}$ & $\mathrm{mgC} \mathrm{m^{-3 }} \mathrm{d}^{-1}$ & $10.3 \pm 6.4$ & $2.8 \pm 2.1^{*}$ & 0.3 \\
\hline
\end{tabular}



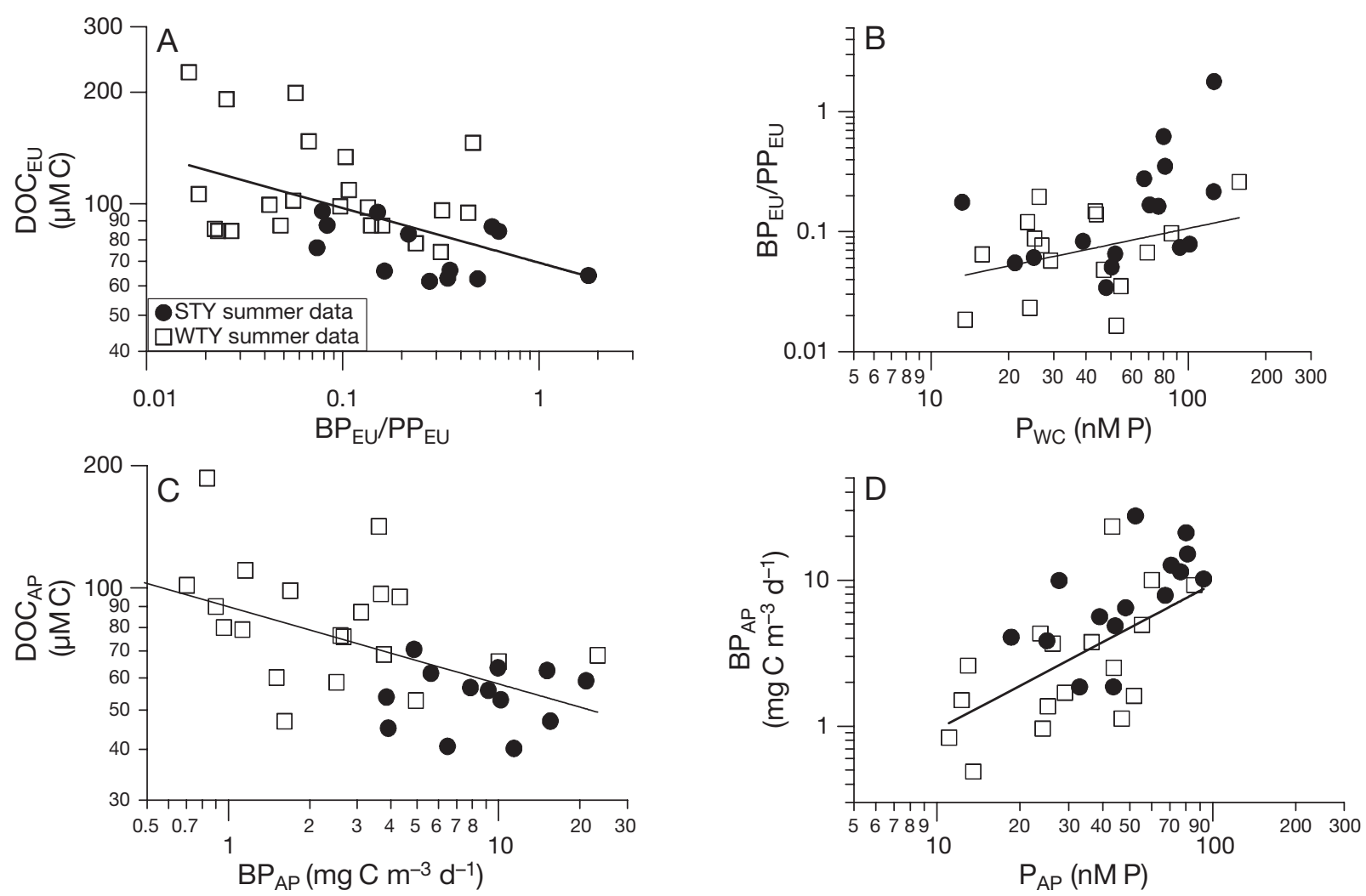

Fig. 6. Scatter plots of depth-averaged measurements derived from summer data (June to September) of strong (STY, 2004 and 2005 , ) and weak typhoon years (WTY, 2006 and 2007, $\square$ ). (A) Euphotic zone dissolved organic carbon concentration (DOC $\mathrm{EU}_{\mathrm{E}}$ $\mu \mathrm{MC})$ versus the ratio of bacterial production to primary production $\left(\mathrm{BP}_{\mathrm{EU}} / \mathrm{PP}_{\mathrm{EU}}\right) ;(\mathrm{B}) \mathrm{BP} \mathrm{EU}_{\mathrm{EU}} / \mathrm{PP}_{\mathrm{EU}}$ versus whole water column phosphate concentration $\left(\mathrm{P}_{\mathrm{WC}}, \mathrm{nMP}\right) ;(\mathrm{C})$ aphotic zone DOC concentration $\left(\mathrm{DOC}_{\mathrm{AP}}\right)$ versus aphotic zone $\mathrm{BP}\left(\mathrm{BP}_{\mathrm{AP}}, \mathrm{mg} \mathrm{C} \mathrm{m}^{-3} \mathrm{~d}^{-1}\right) ;$ and (D) $\mathrm{BP}_{\mathrm{AP}}$ versus aphotic zone $\mathrm{P}$ concentration $\left(\mathrm{P}_{\mathrm{AP}}\right)$. All 4 regression lines represent pooled summer data sets, and were significant at $\mathrm{p}=0.01$. Note $\log$ scale of axes. (A) $\log Y=4.3-0.14 \pm 0.04 \times \log X\left(\mathrm{n}=37, \mathrm{r}^{2}=0.31\right)$; (B) $\log Y=-5.1+0.71 \pm 0.15 \times \log X(\mathrm{n}=32$, $\left.\mathrm{r}^{2}=0.23\right) ;(\mathrm{C}) \log Y=4.5-0.19 \pm 0.05 \times \log X\left(\mathrm{n}=35, \mathrm{r}^{2}=0.33\right) ;$ and $(\mathrm{D}) \log Y=-2.4+1.0 \pm 0.15 \times \log X\left(\mathrm{n}=34, \mathrm{r}^{2}=0.26\right)$

ments were the same, so the results of Expt 4 are used for illustration. Neither the addition of $\mathrm{C}$ nor $\mathrm{N}$ enhanced osmotroph (cyanobacteria and bacteria) growth. However, the addition of $\mathrm{P}$ did cause significant increase of osmotroph abundance (Figs. 7A, B). Note also that in all 4 P-enriched treatments, bacteria responded to added $\mathrm{P}$ earlier than cyanobacteria. Bacterial abundance increased from 17.5 to $27.5 \times$ $10^{8}$ cells $\mathrm{m}^{-3}$ in the first $9 \mathrm{~h}$ (Fig. 7B), while it took more than $48 \mathrm{~h}$ for cyanobacteria to double its abundance (Fig. 7A). The bacterial growth response to P-addition was also observed earlier than that of cyanobacteria in the other 3 experiments. During the incubation period, DOC concentrations remained almost unchanged in the control, C-enriched and $\mathrm{N}$ enriched treatments (data not shown). In the parallel P-enriched treatment of Expt 4, P was depleted within the first $9 \mathrm{~h}$ (Fig. $7 \mathrm{C}$ ) and DOC concentrations dropped linearly from 116 to $45 \mu \mathrm{MC}$ within $32 \mathrm{~h}$ incubation (Fig. 7D), which yielded a DOC consumption rate of $2.22 \mu \mathrm{MC} \mathrm{d}^{-1}$.

\section{DOC consumption experiments}

In these experiments, initial DOC and P concentrations ranged from 51 to $93 \mu \mathrm{MC}$ and $<20$ to $129 \mathrm{nMP}$, respectively. DOC consumption rates varied from 4.1 to $18 \mu \mathrm{M} \mathrm{C} \mathrm{d}^{-1}$ among experiments (Table 2). In the last (13 May) experiment, when ambient $\mathrm{P}$ concentration was undetectable, DOC consumption was also the lowest. However, the DOC consumption rate increased 4fold to a value of $17.9 \mu \mathrm{MC} \mathrm{d}^{-1}$ in the parallel Pamended treatment. Further analysis indicated that DOC consumption rates derived from these experiments were a positive function of initial $\mathrm{P}$ concentrations with a slope of 99:1 C:P d ${ }^{-1}$ (Fig. 8), similar to the Redfield ratio $(\mathrm{C}: \mathrm{P}=106: 1)$. Note also that the in situ 

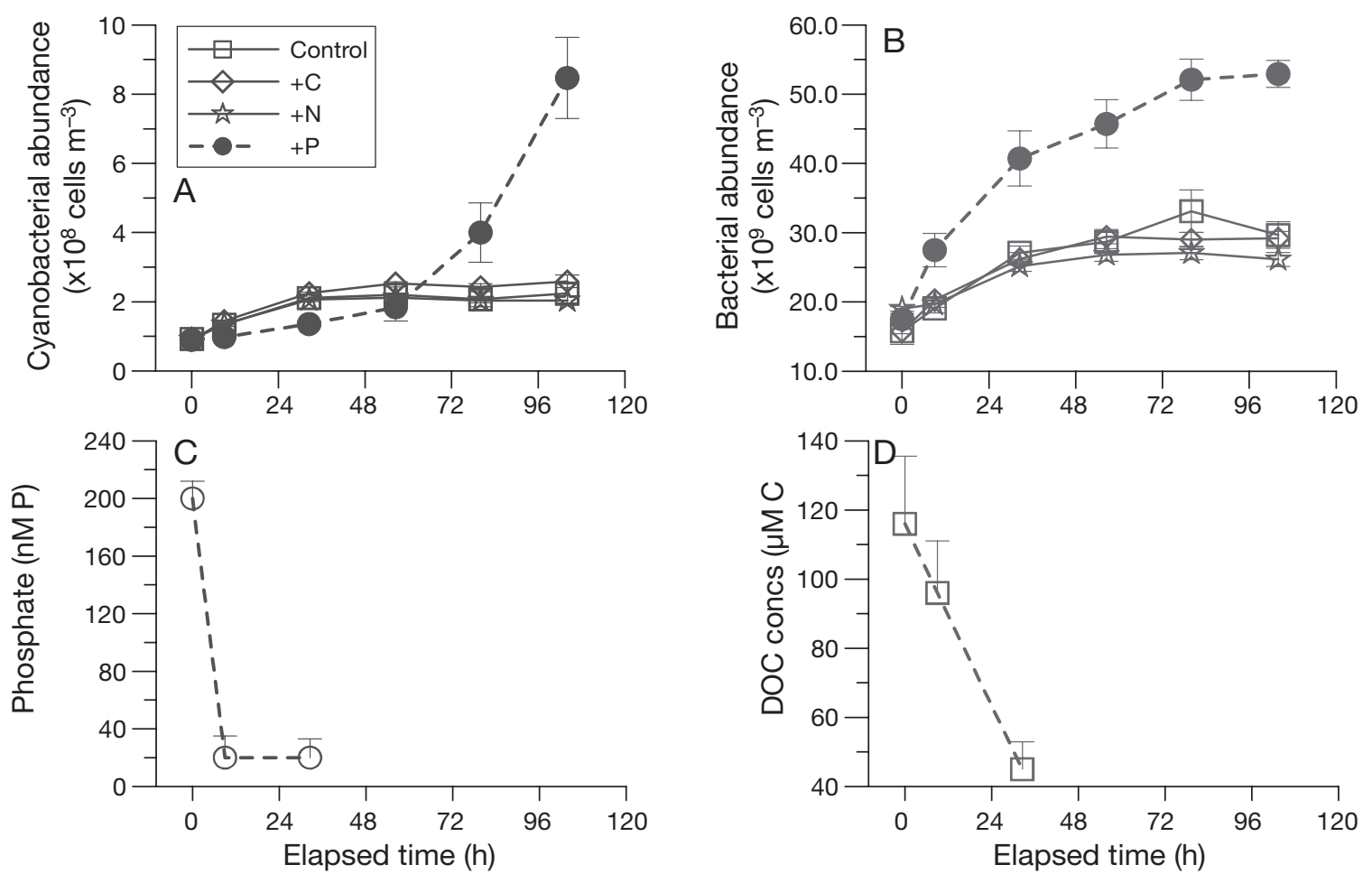

Fig. 7. Changes in (A) cyanobacterial and (B) bacterial abundance under different treatments in the bioassay experiment (Expt 4). $+\mathrm{C},+\mathrm{N}$ and $+\mathrm{P}$ : glucose-, ammonium- and phosphate-enriched treatments, respectively. $(\mathrm{C}, \mathrm{D})$ changes in phosphate and dissolved organic carbon (DOC) concentrations in the parallel P-enriched treatment. Vertical bars indicate SD

temperatures of the first 4 experiments were $\sim 3$ to $\sim 7^{\circ} \mathrm{C}$ lower than room temperature. Actual DOC consumption rates in the field might be lower than those shown in the last column of Table 2.

\section{DISCUSSION}

From a system viewpoint, DOC may come from internal and external sources. The results of the tributary study strongly suggest that the tributaries did not comprise the sources for DOC at the dam site (Fig. 2A). If tributaries were the sources, then a high-low concentration gradient from upstream to downstream should be frequently observed. In fact, the more or less uniform spatial patterns of DOC across the entire basin area implies that the DOC stocks from upstream to downstream might be subjected to similar (biogenic) controlling mechanisms. The comparison of the pre- and post-typhoon cases indicates that strong typhoons had a very minor effect in delivering DOC from the tributaries to the dam site throughout the whole water column (Fig. 3A,B). Conversely, typhoon-induced surface (Fig. 2B) and mid-water (Figs. 3D \& 5A) downstream P-transport was very likely.
There are 2 forms of inorganic $\mathrm{P}$ in the sediments, namely dissolved $\mathrm{P}$ (in the pore-water) and $\mathrm{P}$ absorbed onto particles (i.e. attached P). Strong resuspension and high discharge processes in the shallow tributaries induced by typhoons (Robarts et al. 1998) might deliver dissolved $\mathrm{P}$ to the dam site very quickly (Fig. 4C) via elevated surface run-off. Dissolved P surface transport might be an immediate but short-term pathway for the

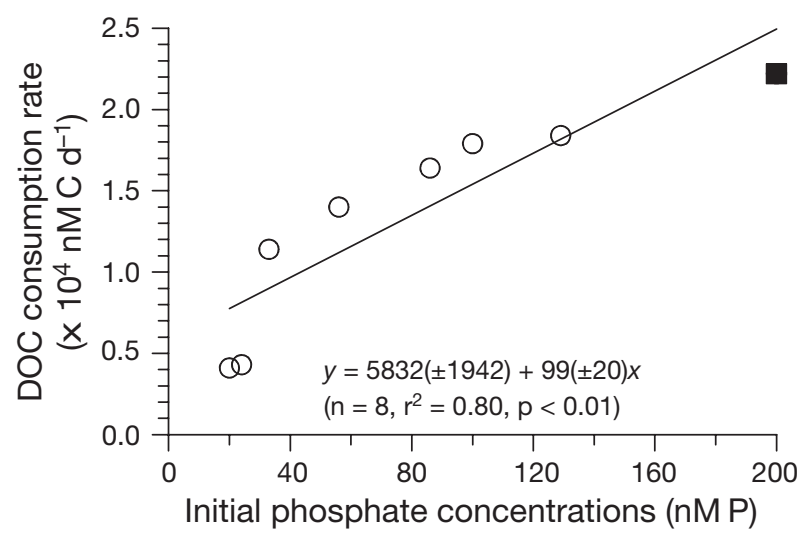

Fig. 8. Scatter plot of dissolved organic carbon (DOC) consumption rate versus initial phosphate concentrations derived from the DOC consumption $(O)$ experiments and bioassay Expt 4 (1) 
growth of phytoplankton and bacteria at the dam site. The amount of attached $\mathrm{P}$ in the hyperpycnal flow in mid-water could be massive, but transported downstream at a slower rate when compared with that of the surface flow (Chen et al. 2006). Like many deep lake systems, deep-water at the dam site during summer is often in a state of hypoxia or even anoxia (data not shown). Attached P would be released as dissolved P in a reduced environment. This mid-water dissolved Pplume (Fig. 5A), when transported upward (by diffusion or diurnal mixing) to the euphotic zone, might serve as a slow but long-term pathway to fuel plankton growth at the dam site (Robarts et al. 1998, Kim et al. 2000).

Several unique DOC features of the dam site study are noted. Firstly, DOC concentrations in shallow and deep water changed within weeks (Fig. 4G), which gave DOC labile to semi-labile characteristics. Bacterial averaged DOC consumption rates $(12.6 \pm 6.3 \mu \mathrm{M} \mathrm{C}$ $\mathrm{d}^{-1}$; Table 2) in the DOC consumption experiments were in the same range as the highest net DOC depletion rates recorded in the euphotic $(13.3 \mu \mathrm{MC}$ $\left.\mathrm{d}^{-1}\right)$ and aphotic zones $\left(7.8 \mu \mathrm{MC} \mathrm{d}^{-1}\right.$; Fig. $\left.4 \mathrm{H}\right)$. The slope $(C: P=99 \pm 20: 1)$ shown in Fig. 8 indicated the stoichiometry of $\mathrm{C}: \mathrm{P}$ consumption in these experiments basically followed that of the Redfield ratio. Secondly, DOC stock varied at multiple time scales. For instance, in 2006 and 2007 when typhoon perturbation was low, there were 10 sharp $\mathrm{DOC}_{\mathrm{EU}}$ (and $\mathrm{DOC}_{\mathrm{AP}}$ ) increases (Fig. 4G). Only 3 out of 10 cases (i.e. Cases 1,2 and 5) occurred in spring, while the rest of the 7 cases occurred in the 2 highly stratified summers. This indicates that the high DOC change rate and DOC anomalies observed in this system are not only seasonal phenomena; they also occur at a time scale shorter than season.

DOC stocks and summer DOC anomalies varied much more dynamically during WTY, signaling strong interannual variation (Figs. 4G,H \& 5C, Table 3). In deep water, the significant influence of $\mathrm{P}_{\mathrm{AP}}$ on $\mathrm{BP}_{\mathrm{AP}}$ (Fig. 6D) and $\mathrm{BP}_{\mathrm{AP}}$ on $\mathrm{DOC}_{\mathrm{AP}}$ (Fig. $6 \mathrm{C}$ ) suggests that mineral control of bacterial activity (i.e. C consumption) might play a crucial role in determining the change in DOC concentrations. This can be further justified by the significant correlation of $\mathrm{P}$ availability with DOC consumption rates in the biodegradation experiments (Fig. 8). In the euphotic zone, the variation in $\mathrm{DOC}_{\mathrm{EU}}$ could be expressed as a negative function of the $\mathrm{BP}_{\mathrm{EU}} /$ PP ratio (Fig. 6A), signifying that biogenic sources (PP) and sinks $\left(\mathrm{BP}_{\mathrm{EU}}\right)$ might play interactive roles in determining the size of the DOC stock in the upper water column. Additionally, the positive correlation between $\mathrm{P}_{\mathrm{WC}}$ and the $\mathrm{BP}_{\mathrm{EU}} / \mathrm{PP}$ ratio (Fig. $6 \mathrm{~B}$ ) indicates that $\mathrm{P}$ supply from deep water could be crucial for the change in the ratio.
Phytoplankton-bacteria relationships may span from symbiotic to parasitic (for review, see Grossart et al. 2005). Whether these relationships tend to one side or the other greatly depends on environmental conditions (e.g. nutrient supply) and, presumably, the function of bacteria present. Competition for the same limiting resource is critical in shaping the interactions (i.e. production ratio) between bacteria and phytoplankton. Grossart (1999) demonstrated that growth of both bacteria and algae was significantly enhanced when inorganic nutrients were plentiful. On the other hand, bacteria could inhibit algal growth when inorganic nutrients were limiting. Many mesocosm and bottle experiments have revealed that the addition of limiting nutrients could facilitate bacterial DOC degradation. Shiah et al. (1998) showed that DOC turnover rate in the western Equatorial Pacific could be enhanced by 2to 9-fold when inorganic nutrients were added. Similar findings have also been reported in the Baltic and Mediterranean Seas (Zweifel et al. 1993), the North Atlantic Ocean (Kirchman et al. 1991), the Gulf of Mexico (Pomeroy et al. 1995) and even estuarine ecosystems (Shiah \& Ducklow 1995).

During the warm period, P-limitation on bacteria and algae (cyanobacteria) was evident, as shown in the bioassay experiments (Fig. 7A,B). Moreover, the faster response of bacteria to P-enrichment than algae suggests that, in the field, the P-pulse introduced by typhoons might relieve bacteria more than phytoplankton from P-limitation. It has been well documented that in P-deficient systems, bacteria were responsible for the major uptake of limiting $\mathrm{P}$ due to their superior competition capacity (Currie \& Kalff 1984, Thingstad et al. 1997, Vadstein 2000). The results of the summer interannual comparison (Table 3) showed that both PP and $\mathrm{BP}_{\mathrm{EU}}$ were enhanced due to the extra $\mathrm{P}$ supply from strong typhoons. However, as indicated in Table 3 , such enhancement of $\mathrm{BP}_{\mathrm{EU}}$ (by $125 \%$ ) was $\sim 6$-fold of that of PP (by $22 \%$ ). This verifies that bacteria had a much higher P requirement than phytoplankton (Vadstein et al. 1988, 1993) and that bacteria may be much more sensitive than algae to $\mathrm{P}$ pulses.

The following scenario is proposed to illustrate the effect of typhoons on DOC dynamics. In the summers of STY, the new P introduced by a strong typhoon might relieve bacteria more than algae from P-starvation, resulting in a higher $\mathrm{BP}_{\mathrm{EU}} / \mathrm{PP}$ ratio so that the newly produced DOC is quickly consumed. Similarly, typhoondelivered new $\mathrm{P}$ in the mid-waters might fuel bacterial C-consumption substantially at depth, which could bring about very low $\mathrm{DOC}_{\mathrm{AP}}$ concentrations and thus the absence of a DOC anomaly. In contrast, in the summer of WTY, biogenic DOC still could be continuously produced by high algal C-synthesis rates, while bacterial production throughout the water column is substan- 
tially hindered due to the lack of episodic P supply. This might favor the formation of the DOC anomalies. Additionally, this could be ascribed to a higher percentage of algal exudates in relation to PP when P-limitation is more severe in WTY. Several investigations have shown elevated DOC release from phytoplankton occurring when inorganic nutrient supply is insufficient (for review, see Obernosterer \& Herndl 1995).

\section{CONCLUSIONS}

Through the analysis of extensive data sets, the present study demonstrates potential mechanisms and pathways connecting DOC dynamics with biological interactions affected by typhoons at multiple time (seasonal to interannual) and spatial (tributaries versus dam site and euphotic versus aphotic) scales. The present study specifically emphasizes that the $\mathrm{P}$ pulses introduced by multiple strong typhoons indeed favor a closer coupling between auto- and heterotrophs so that DOC concentrations tend to vary in a less significant way. Oligotrophic systems comprise a large proportion of the ocean ecosystem. It is logistically difficult to investigate the influence of typhoons on DOC dynamics in the open ocean due to the difficulty in taking samples under bad weather conditions, and the lack of (satellite) remote-sensing facilities monitoring DOC and bacterial production, as well as strong water-mass mixing. It is noted that reservoirs differ from the open ocean in many ways, including geographic features (bottom depth) and related water column structure and stability. However, our hypothesis, if applicable to the open ocean, may substantially expand our perception of the cycling and export of biogenic DOC, which has long been regarded as an important component of global C-cycling.

Acknowledgements. The Taipei Fei-Tsui Reservoir Administration Bureau is thanked for assistance with the field work. Funding for this research comes from NSC-Taiwan and Academia Sinica thematic (AFOBi-RCEC) project.

\section{LITERATURE CITED}

Ammerman JW, Fuhrman JA, Hagström ^, Azam F (1984) Bacterioplankton growth in seawater: I. Growth kinetics and cellular characteristics in seawater cultures. Mar Ecol Prog Ser 18:31-39

Azam F (1998) Microbial control of oceanic carbon flux: the plot thickens. Science 280:694-696

Billen G, Fontigny A (1987) Dynamics of a Phaeocystis-dominated spring bloom in Belgian coastal waters. II. Bacterioplankton dynamics. Mar Ecol Prog Ser 37:249-257

Carlson CA, Ducklow HW, Michaels AF (1994) Annual flux of dissolved organic carbon from the euphotic zone in the northwestern Sargasso Sea. Nature 371:405-408
Chen YJC, Wu SC, Lee BS, Hung CC (2006) Behavior of storm-induced suspension interflow in subtropical Feitsui Reservoir, Taiwan. Limnol Oceanogr 51:1125-1133

> Cho BC, Azam F (1988) Major role of bacteria in biogeochemical fluxes in the ocean's interior. Nature 332:441-443

Copin-Montegut G, Avril B (1993) Vertical distribution and temporal variation of dissolved organic carbon in the north-west Mediterranean Sea. Deep-Sea Res I 40: 1963-1972

$>$ Currie D, Kalff J (1984) The relative importance of bacterioplankton and phytoplankton in phosphorus uptake in freshwater. Limnol Oceanogr 29:311-321

> Del Giorgio PA, Cole JJ, Cimblerist A (1997) Respiration rates in bacteria exceed phytoplankton production in unproductive aquatic systems. Nature 385:148-151

Dickey TD, Nelson N (1996) In the eye of the storm: Bermuda mooring records hurricane's passage. US JGOFS Newsl Sep:5-6

Ducklow HW, Carlson CA (1992) Oceanic bacterial production. In: Marshall KC (ed) Advances in microbial ecology, Vol 12. Plenum Press, New York, NY, p 113-181

Edwards AL (1985) Multiple regression and the analysis of variance and covariance. W. H. Freeman, New York, NY

Fuhrman JA (1992) Bacterioplankton roles in cycling of organic matter: the microbial food web. In: Falkowski PG, Woodhead $\mathrm{AD}$ (eds) Primary productivity and biogeochemical cycles in the sea. Plenum Press, New York, NY, p 361-383

Fuhrman JA, Azam F (1982) Thymidine incorporation as a measurement of heterotrophic bacterioplankton production in marine surface waters: evaluation and field results. Mar Biol 66:109-120

Grossart HP (1999) Interactions between marine bacteria and axenic diatoms (Cylindrotheca fusiformis, Nitzschia laevis, and Thalassiosira weissflogii) incubated under various conditions in the lab. Aquat Microb Ecol 19:1-11

Grossart HP, Levold F, Allgaier M, Simon M, Brinkhoff T (2005) Marine diatom species harbour distinct bacterial communities. Environ Microbiol 7:860-873

> Hansell DA, Carlson CA (1998) Deep-ocean gradients in the concentration of dissolved organic carbon. Nature 395: 263-266

Hedges JI (1992) Global biogeochemical cycles: progress and problems. Mar Chem 39:67-93

Hobbie JE, Daley RJ, Jasper S (1977) Use of nuclepore filters for counting bacteria by fluorescence microscopy. Appl Environ Microbiol 33:1225-1228

Hubbard JG, Chrzanowski TH (1986) Impact of storms on heterotrophic activity of epilimnetic bacteria in a southwestern reservoir Appl. Environ Microbiol 51:1259-1263

> Ittekkot V, Brockmann U, Michaelis W, Degens ET (1981) Dissolved free and combined carbohydrates during a phytoplankton bloom in the northern North Sea. Mar Ecol Prog Ser 4:299-305

> Kim B, Choi K, Kim C, Lee UH, Kim YH (2000) Effects of the summer monsoon on the distribution and loading of organic carbon in a deep reservoir, Lake Soyang, Korea. Water Res 34:3495-3504

Kirchman DL, Suzuki Y, Garside C, Ducklow HW (1991) High turnover rates of dissolved organic carbon during a spring phytoplankton bloom. Nature 352:612-614

Lin II, Liu WT, Wu CC, Wong GTF and others (2003) New evidence for enhanced ocean primary production triggered by tropical cyclone. Geophys Res Lett 30, 1718, doi: 10.1029/2003GL017141

Longhurst AR, Harrison WG (1989) The biological pump: profiles of plankton production and consumption in the upper ocean. Prog Oceanogr 22:47-123 
Obernosterer I, Herndl GJ (1995) Phytoplankton extracellular release and bacterial growth: dependence on the inorganic N:P ratio. Mar Ecol Prog Ser 116:247-257

Parsons TR, Maita Y, Lalli CM (1984) A manual of chemical and biological methods for seawater analysis. Pergamon Press, New York, NY

Pomeroy LR, Sheldon JE, Sheldon WM Jr, Peters F (1995) Limits to growth and respiration of bacterioplankton in the Gulf of Mexico. Mar Ecol Prog Ser 117:259-268

Redfield AC, Ketchum BH, Richards FA (1963) The influence of organisms on the composition of sea water. In: Hill MN (ed) The sea. Wiley-Interscience, New York, NY, p 26-77

Robarts RD (1987) Effect of rainstorms on heterotrophic bacterial activity in a hypertrophic African lake. Hydrobiologia 148:281-286

Robarts RD, Waiser MJ, Hadas O, Zohary T, MacIntyre S (1998) Relaxation of phosphorus limitation due to typhooninduced mixing in two morphologically distinct basins of Lake Biwa, Japan. Limnol Oceanogr 43:1023-1036

Shiah FK, Ducklow HW (1995) Regulation of bacterial abundance and production by substrate supply and bacterivory: a mesocosm study. Microb Ecol 30:239-255

Shiah FK, Kao SJ, Liu KK (1998) Bacterial production in the western equatorial Pacific: implications of inorganic nutri-

Editorial responsibility: Fereidoun Rassoulzadegan, Villefranche-sur-Mer, France ent effects on dissolved organic carbon accumulation and consumption. Bull Mar Sci 63:795-808

Shiah FK, Chung SY, Kao SJ, Gong GC, Liu KK (2000) Biological and hydrographical responses to tropical cyclones (typhoons) in the continental shelf of the Taiwan Strait. Contin Shelf Res 20:2029-2044

Thingstad TF, Hagstrom A, Rassoulzadegan F (1997) Accumulation of degradable DOC in surface waters: Is it caused by a malfunctioning microbial loop? Limnol Oceanogr 42:398-404

Vadstein OA (2000) Heterotrophic, planktonic bacteria and cycling of phosphorus: phosphorous requirement, competitive ability, and food-web interactions. Adv Microb Ecol 16:115-167

Vadstein O, Jensen A, Olsen Y, Reinertsen H (1988) Growth and phosphorus status of limnetic phytoplankton and bacteria. Limnol Oceanogr 33:489-503

Vadstein OA, Olsen Y, Reinertsen HR, Jensen A (1993) The role of planktonic bacteria in phosphorus cycling in lakes: sink and link. Limnol Oceanogr 38:1539-1544

Williams PJleB, Bowers DG (1999) Regional carbon imbalances in the oceans. Science 284:1735

> Zweifel UL, Norrman B, Hagström Å (1993) Consumption of dissolved organic carbon by marine bacteria and demand for inorganic nutrients. Mar Ecol Prog Ser 101:23-32

Submitted: September 7, 2009; Accepted: April 26, 2010

Proofs received from author(s): July 2, 2010 